\title{
Tabligh K.H. Acep Dawud Melalui Pendekatan Dialog Keagamaan
}

\author{
IsmiAlawiah $^{1 *}$, Dindin Solahudin $^{2}$, Nase $^{1}$ \\ ${ }^{1}$ Jurusan Komunikasi dan Penyiaran Islam, Fakultas Dakwah dan Komunikasi, UIN Sunan \\ Gunung Djati, Bandung \\ 2JurusanPengembanganMasyarakat Islam, Fakultas Dakwah dan Komunikasi, UIN Sunan \\ Gunung Djati, Bandung \\ *Email : ismialawiab7@gmail.com
}

\begin{abstract}
ABSTRAK
Tulisan ini bertujuan untuk mengetahui kiprah dakwah K.H. Acep Dawud sebagai seorangmubaligh, yang menyampaikantablighnyamelaluipendekatan dialog keagamaan, proses tabligh yang dilakukan dan materi tabligh yang disampaikannya melalui pendekatan dialog keagamaan. Metode penelitian menggunakan metode deskriptif, yakni untuk memaparkan situasi atau peristiwa yang terjadi danmemperoleh gambaran yang sistematis dan ilmiah tentang tabligh melalui pendekatan dialog keagamaan yang dilakukan oleh K.H. Acep Dawud. Analisis data dengan analisis kualitatif. Dari hasil penelitian menunjukan bahwa kiprah dakwah K.H Acep Dawud melalui dialog keagamaannya yaitu menghapuskan penyimpangan keagamaan, seperti praktikpraktik perdukunan dan klenik serta membantu masyarakat dalam menyelesaikan masalah-masalah mereka dengan solusi yang dianggap memudahkan mereka. Sedangkan proses tabligh K.H. Acep Dawud dalam kegiatan dialog keagamaannya menggunakan metode dialog eklektik, dan materi tabligh beliau meliputi tiga aspek pesan tabligh yakni akidah, akhlak, dan syari'at.
\end{abstract}

Kata Kunci :Tabligh; Dialog; Keagamaan

\section{ABSTRACT}

Tabligh has the most important role in broadcasting Islam. This paper aims to find out the progress of K.H propaganda. AcepDawnd as a preacher, who delivered his message through the approach of religious dialogue, the tabligh process carried out and the material of tabligh which he conveyed through the approach of religious dialogue. The research method uses descriptive methods, namely to describe the situation or event that occurred and obtain a systematic and scientific picture of the tabligh through a religious dialogue approach carried out by K.H. AcepDawnd. Data analysis with qualitative analysis. From the results of the study, 
it was shown that the role of the missionary of $K$. AcepDawnd through his religious dialogue was to abolish religious deviations, such as shamanism and occult practices and to help the community to solve their problems with solutions that were considered to facilitate them. While the K.H tabligh process. AcepDawnd in his religious dialogue activities used the method of eclectic dialogue, and his tabligh material included three aspects of the tabligh message, namely faith, morality, and shari'ah.

Keywords: Tabligh; Dialog; Religious

\section{PENDAHULUAN}

Dakwah dapat diartikan pula sebagai dorongan untuk manusia, supaya mengikuti kebenaran dan petunjuk, menyeru mereka untuk berbuat kebajikan dan melarang mereka dari perbuatan munkar agar mereka mendapat kebahagiaan di dunia maupun akhirat (Rafi'udin dan Maman, 1997:24).Sehingga sebagai suatu ajaran Islam sekaligus suatu agama, dakwah tidak disampaikan secara kasar atau memaksa manusia untuk memeluk agama Islam, tetapi dakwah disampaikan dengan lemah lembut kepada manusia agar tidak ada paksaan dalam menyampaikan ajarannya.

Usaha dalam menyebarkan ajaran Islam, di tengah masyarakat merupakan bagian dari usaha dakwah yang seharusnya dilakukan dalam kondisi apapun dan bagaimanapun yang harus dilaksanakan oleh manusia sebagai khalifah di muka bumi. Oleh karena dakwah merupakan salahsatu tugas manusia sebagai khalifah di muka bumi, maka dakwah sudah direncanakan sejak awal mula penciptaan manusia, bahkan sampai saat ini, dakwah pun telah berkembang menjadi sebuah ilmu. Kemudian muncul pula kategori-kategori dakwah mengenai ilmu dakwah oleh para ilmuan dakwah tersebut, salah satunya yaitu tabligh.

Pada dasarnya pola tabligh tidak jauh berbeda dengan pola komunikasi yaitu mubaligh- maudu- uslub- washilah- mubalagh. Adapun dalam perkembanganya kegiatan tabligh memiliki beberapa metode (cara) agar pesan tabligh dapat tersampaikan dengan baik, antara lain yaitu dengan metode ceramah, metode diskusi, metode dialog, metode konsultasi, metode karya tulis, metode pemberdayaan masyarakat, metode dakwah rosul, metode pendidikan dan pengajaran, serta metode kelembagaan (Aziz, 2009: 359-381).

Dalam menyampaikan seruan, bukan suatu hal yang mudah dilakukan, tanpa ditunjang oleh pengetahuan yang cukup tentang tata cara penyampaian pesan-pesan secara efektif, dan untuk mencapai hasil yang maksimal. Akan tetapi seorang mubaligh harus mempunyai beberapa pengetahuan mengenai aspekaspek tabligh di antaranya: materi tabligh, metode tabligh dan mengetahui kondisi mubalagh-nya, sehingga pesan yang disampaikan oleh seorang mubaligh dapat dicerna dan dipahami sesuai dengan kondisi dan tingkat pengetahuan mubalaghnya(Muhyidin, 2002: 56).

Mayoritas kegiatan tabligh di daerah pedesaan, biasanya dilakukan secara 
Tabligh K.H. Acep Dawud Melalui Pendekatan Dialog Keagamaan

langsung, seperti halnya pengajian atau majelis taklim, tabligh akbar, hingga melakukan dialog secara langsung dengan masyarakat. Hal ini di sebabkan karena waktu dan rutinitas yang dilakukan masyarakat di daerah pedesaan yang relative masih dibilang rendah. Dari sekian banyak metode tabligh yang dapat digunakan, tabligh melalui pendekatan dialog memang dianggap lebih efektif di karenakan banyaknya masalah yang tidak cukup diselesaikan hanya dengan menggunakan metode ceramah. Sebagaimana diungkapkan oleh M. Ali Aziz, bahwa "Dialog merupakan wawancara secara individual atau tatap muka antara seorang mubaligh yang profesional dengan mubalagh untuk memecahkan masalah yang dihadapinya" (Aziz, 2009: 372), dari pengertian tersebut, dapat dipahami bahwa seorang mubaligh yang berdialog tentang agama haruslah orang yang profesional. Pada kasus masyarakat di daerah pedesaan, orang yang dianggap paling profesional dan berhak untuk bicara tentang keagamaan adalah seorang kiai.

Masyarakat di pedesaan sangat menjungjung tinggi dan menghormati kiai atau ustadz yang ada dilingkungan sekitarnya. Hal demikian dianggap, karena seorang kiai adalah hal utama sebagai sesepuh dan orang yang berilmu di lingkungannya, sehingga masyarakat biasanya sangat mudah menerima apa saja yang disampaikan oleh seorang kiai atau ustadznya. Dengan demikian, kiai adalah sosok seorang mubaligh utama sekaligus sebagai sumber kebenaran utama bagi masyarakat pedesaan.

K.H. Acep Dawud merupakan seorang kiai sekaligus sesepuh di Cimaya, tepatnya di Desa Cintaasih Kabupaten Bandung Barat. Beliau juga menjadi pendiri sekaligus pimpinan Pondok pesantren Riyadul Hikmah yang terletak di desa tersebut. K.H. Acep Dawud menjadi tolak ukur kebenaran bagi masyarakat Desa Cintaasih. Disamping masyarakat sekitar Desa Cintaasih, K.H. Acep Dawud sering pula mendapatkan tamu untuk berdialog dari luar daerah, seperti Cianjur, Bogor, Subang, bahkan hingga Jawa Tengah dan Jawa Timur dan ada pula yang dari luar negeri. Meskipun letak geografis Pondok Pesantren Riyadul Hikmah ini, tidak terlalu strategis (tidak memiliki akses jalan yang baik dan terdapat di desa terpencil), namun hal itu tidak menjadi penghalang bagi para tamu dan santri-santri yang berasal dari luar daerah, untuk menuntut ilmu atau sekedar bertamu untuk berdialog dengan K.H. Acep Dawud di pesantren tersebut.

Beberapapenelitian yang berkaitandengantablighdiantaranyapenelitian dengan judul Pendekatan Tabligh Forum Silaturabmi Lembaga Dakwah Kampus Bandung Raya (FSLDK BARAYA) Terbadap Anak Jalanan, oleh Ceng Muklis. Metode yang digunakan dalam penelitian ini adalah metode deskriptif, dengan pendekatan kualitatif. Hasil penelitian menunjukkan bahwa pendekatan tabligh FSLDK BARAYA menggunakan pendekatan mentoring, materi yang disampaikan oleh mereka berupa materi tentang akhlak dan akidah, serta keberhasilan yang dicapai merupakan perubahan sifat para anak jalanan menjadi 
lebih positif.

Selanjutnya penelitian dengan judul Tabligh Melalui Media Sosial Line (Studi Deskriptif Pada Akun Official "Dunia Jilbab"), yang diteliti oleh Indah Purnama Putri. Metode yang digunakan dalam penelitian ini adalah metode deskriptif dengan pendekatan kualitatif. Hasil penelitian menunjukkan proses tabligh di media Line dibagi menjadi empat komponen, yaitu mengetahui sumber komunikator/mubaligh, mengetahui sumber pesan, mengetahui saluran yang digunakan dan menghasilkan sebuah respon likes dan comment, dan pemanfaatkan media sosial Line sebagai media tabligh yaitu dengan menggabungkan dua metode dakwah online dan tatap muka yang dipandang efektif. Selain itu, ada pula penelitian yang dilakukan oleh Muhammad Solahudin, dengan judul Tabligh Ustad Hari Wibowo Melalui Media Wayang Golek (Si Cepot). Penelitian ini menggunakan metode deskriptif dengan pendekatan kuantitatif. Tujuan dari penelitian ini adalah untuk mengetahui materi dan metode apa yang digunakan oleh Ust. Hari Wibowo dalam kegiatan tablighnya menggunakan wayang golek. Hasil penelitian tersebut menunjukan bahwa materi tabligh yang disampaikan merupakan materi akidah ketuhanan, akhlak, dan 'ubudiyah. Sedangkan metode yang digunakan berupa metode ceramah.

Dari uraian diatas, maka yang membedakan penelitian ini dengan penelitian-penelitian di atas adalah, dalam penelitian ini, dilakukan penelitian mengenai tabligh dengan pendekatan dialog keagamaan yang dilakukan oleh K.H. Acep Dawud di Desa Cintaasih.Penelitian ini dimaksudkan untuk meneliti kegiatan tabligh yang dilakukan oleh K.H. Acep Dawud. Penelitian ini akan bermanfaat untuk kajian ilmu dakwah, khususnya dalam bidang tabligh melalui pendekatan dialog keagamaan.

Riset ini bertujuan untukmengetahui kiprah dakwah K.H. Acep Dawud di Pondok Pesantren Riyadul Hikmah Cimaya, mengetahui proses tabligh melalui pendekatan dialog keagamaan yang dilakukan oleh K.H. Acep Dawud, dan untuk mengetahui materi tabligh melalui pendekatan dialog keagamaan yang disampaikan oleh K.H. Acep Dawud. Untuk itu, penelitian ini difokuskan padakegiatantabligh yang dilakukanoleh KH. AcepDawud, dengan memberi judul penelitian sebagai; Tablighmelaluipendekatan dialog keagamaan.

Metode yang digunakan dalam penelitian ini adalah metode deskriptif yang bertujuan untuk menggambarkan tabligh melalui pendekatan dialog keagamaan yang dilakukan oleh K.H. Acep Dawud Pimpinan Pondok Pesantren Riyadul Hikmah Cimaya Desa Cintaasih Kabupaten Bandung Barat dengan menggunakan pendekatan kualitatif. Adapun untuk kegunaan metode deskriptif ini, yaitu untuk memperoleh gambaran yang sistematis dan ilmiah tentang tabligh melalui pendekatan dialog keagamaan yang dilakukan oleh K.H. Acep Dawud dilihat dari kiprah dakwah K.H. Acep Dawud sebagai seorang mubaligh yang profesional, proses tabligh yang dilakukannya dan materi tabligh yang 
Tabligh K.H. Acep Dawud Melalui Pendekatan Dialog Keagamaan disampaikannyamelalui kegiatan dialog keagamaan.

\section{LANDASAN TEORITIS}

Kata tabligh berasal dari akar kata ballagha, yuballighu, tabliighan, yang diartikan menyampaikan. Tabligh merupakan kata kerja transitif yang berarti menyampaikan atau melaporkan. Dalam konteks ajaran Islam, tabligh adalah proses penyampaian dan penyiaran mengenai ajaran-ajaran Islam kepada umat manusia. Dalam konsep Islam, tabligh merupakan salah satu perintah yang dibebankan kepada para utusan-Nya (Sukayat, 2009: 87-86). Dalam Alquran kata tabligh bermakna menyampaikan seperti dalam surah Al-Maidah ayat 67:

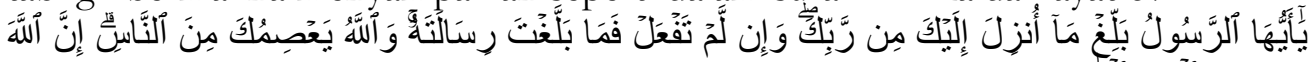

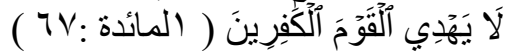

"Wahai Rasul! sampaikanlah apa yang diturunkan Tuhanmu kepadamu, jika tidak engkau lakukan (apa yang diperintahkan itu) berarti engkau tidak menyampaikan amanat-Nya, dan Allah memelihara engkau dari (gangguan) manusia. Sungguh Allah tidak memberi petunjuk kepada orang-orang kafir" (Depag, 2010: 119).

Secara theologis (Ridwan, 2011: 201) mengemukakan:

Tabligh dalam pandangan madzhab kalam Asy'ariyah merupakan sebuah sifat yang wajib dimiliki oleh Rasulullah Saw, yang dimana pada prinsipnya isi pokok dalam kegiatan tabligh tersebut adalah menyuruh kepada kebaikan dan mencegah dari perbuatan munkar. Kegiatan tabligh awal mula dilakukan oleh Rasulullah Saw sendiri, kemudian dilakukan oleh para saghabat dan selanjutnya menjadi sebuah kewajiban bagi setiap muslim sesuai dengan kemampuan yang mereka miliki.

Menurut Amrullah Ahmad, tabligh merupakan proses menyampaikan pesan Islam yang dilakukan oleh individu maupun kelompok baik secara lisan maupun tulisan (dalam Azis, 2004: 21). Sedangkan Ibrahim Imam, tabligh adalah memberikan informasi yang benar, pengetahuan yang faktual dan hakikat yang pasti bisa menolong dan membantu manusia untuk membentuk pendapat yang tepat dalam suatu kejadian atau dari berbagai kesulitan. Adapun pendapat Sayyid Quthub, tabligh berarti menyampaikan dan menyeru manusia kepada kebenaran agama, yang dibawa kepada umatnya (Quthub, 1984: 604).

Dalamkegiatantablightentunyatakluput pula mengenaiunsur-unsurnya. Pada dasarnya unsur-unsur tabligh yang harus ada dalam kegiatan tabligh, tidak jauh berbeda dengan unsur-unsur yang ada pada kegiatan dakwah dan komunikasi. Seperti yang dikatakan oleh Laswell, bahwa komunikasi itu meliputi komunikor, pesan, media, dan komunikan. Begitu pula dengan tabligh, unsurunsur dalam kegiatan tabligh meliputi mubaligh, pesan/materi (maudu) tabligh, media (washilah) tabligh, metode (ushlub) tabligh dan mubalagh. 
Menurut Zins (1993), dialog ialah suatu proses yang biasanya didasarkan pada karakteristik hubungan yang sama yang ditandai dengan saling mempercayai dan komunikasi yang terbuka, bekerja sama dalam mengidentifikasikan masalah, menyatukan sumber-sumber pribadi untuk mengenal dan memilih strategi yang mempunyai kemungkinan dapat memecahkan masalah yang telah diidentifikasi, dan pembagian tanggung jawab dalam pelaksanaan dan evaluasi program atau strategi yang telah direncanakan.

Adapun pengertian dialog menurut M. Ali Aziz, merupakan wawancara secara individual atau tatap muka antara seorang mubaligh yang profesional dengan mubalagh untuk memecahkan masalah yang dihadapinya (Aziz, 2009: 372). Sofyan S. Willis, mendefinisikan bahwa dialog sebagai upaya pemberian bantuan seseorang yang profesional dan berpengalaman, agar klien dapat mengembangkan potensinya secara optimal, dapat menyesuaikan dirinya dengan lingkungan sekitar serta dapat mengatasi masalah yang dihadapinya (Willis, 2011: 17).

Dari beberapa pengertian mengenai dialog di atas, dapat disimpulkan bahwa dialog adalah sebuah percakapan, yang di dalamnya terdapat aktivitas berbagi dan bertukar informasi anatara seorang konsultan dengan pihak yang berdialog untuk mengetahui tentang suatu masalah yang dihadapi. Dialog adalah sebuah proses, karena merupakan sebuah proses yang interatif dan berjalan. Dialog adalah percakapan antar manusia, karena melibatkan individu-individu yang berpartisifasi, dan berdialog adalah mengenai aksi dan hasil, karena sebuah pandangan yang dikonsultasikan mengarah kepada sebuah pengambilan keputusan.Selain itu pula, pada dasarnya dialog adalah suatu aktifitas pemberian nasehat berupa anjuran-anjuran dan saran-saran dalam bentuk pembicaraan yang komunikatif antara konselor dan klien, yang mana dialog datang dari pihak klien yang disebabkan karena ketidaktahuan atau permasalahan yang dihadapinya (Bakran, 2001: 180).

Dialog merupakan sebuah kegiatan pertalian timbal balik dua orang, yang satu bertindak sebagai konselor atau dikatakan pula sebagai mubaligh, sedang yang lainnya sebagai klien (mubalagh). Kegiatan tersebut bertujuan untuk mencapai pengertian tentang diri sendiri dalam hubungannya dengan masalah yang sedang dihadapi, ataupun yang akan datang (Wijaya, 1988: 122). Metode dialog dalam kegiatan tabligh merupakan aktivitas wawancara antara seorang mubaligh, dengan mubalagh, guna memecahkan masalah atau hanya sekedar menenangkan hati sang klien (Aziz, 2012: 372).

Menurut Juhana Wijaya, "setidaknya ada tiga macam teknik dalam aktivitas dialog, yakni teknik non-derektif, teknik derektif, dan teknik eklektik" (Wijaya, 1988: 128). Pertama, teknik non-derektif. Pada teknik ini, seorang mubaligh memiliki keyakinan bahwa mubalaghnya dapat menyelesaikan masalahnya sendiri. Dalam teknik ini, seorang mubalagh diberikan kebebasan untuk 
mencurahkan semua isi hatinya, sedangkan mubaligh sebagai konselor, hanya bertugas menerima dan memantulkan curahan hati mubalaghnya.

Kedua, teknik direktif. Teknik ini merupakan kebalikan dari teknik pertama, dimana dalam teknik ini, mubaligh meyakini bahwa mubalaghnya tidak memiliki kemampuan sama sekali dalam menyelesaikan masalahnya. Dalam teknik ini, mubalagh melakukan analisis, sintesis, diagnosis, dan prognosis sendiri, untuk kemudian menciptakan hubungan baik dengan mubalagh, menafsirkan keluh-kesah mubalagh dan memberikan sedikit nasehat yang diperlukan (Wijaya, 1988: 129).

Ketiga, teknik eklektik. Teknik ini adalah perkawinan antara dua teknik sebelumnya. Seorang mubaligh dengan sangat fleksibel menggunakan kedua teknik sebelumnya, sesuai dengan kondisi dan suasana kegiatan berdialog (Wijaya, 1988: 129).

Dari pendapat diatas, dapat disimpulkan bahwa kegiatan tabligh dengan menggunakan metode dialog akan lebih efektif jika dilakukan antar personal, tidak berbasis kelompok. Hal ini dikarenakan seorang mubalagh akan lebih terbuka kepada mubaligh, jika kegiatan tersebut dilakukan secara pribadi, yang dalam model komunikasidakwahmenurutscrahman (dalamsaepuloh, 2009: 665)termasukkedalamkomunikasiantarpribadi.

\section{HASIL DAN PEMBAHASAN}

Riyadul Hikmah merupakan satu-satunya Pondok Pesantren yang berdomisili di Desa Cintaasih. Pondok Pesantren tersebut didirikan oleh K.H Acep Dawud (selaku sesepuh Desa Cintaasih) di Kp. Cimaya Rt 003 Rw 003 Desa Cintaasih Kecamatan Cipongkor Kabupaten Bandung Barat. Pondok Pesantren Riyadul Hikmah ini, terletak di sebuah perkampungan terpencil yang tidak memiliki akses jalan yang baik.Pada mulanya Pondok Pesantren Riyadul Hikmah ini hanyalah sebidang tanah warisan berukuran kecil yang diberikan kepada K.H. Acep Dawud dari ayahnya. Kemudiandibangunlah sebuah tajug (masjid kecil) diatas tanah tersebut, dengan kapasitas sekitar lima orang saja.tajug tersebut beliau gunakan untuk sekedar berbagi ilmu dengan para warga, khususnya generasi penerus bangsa. Dengan adanya tajug tersebut, beberapa anak-anak kecil disekitar desa mulai berdatangan untuk menuntut ilmu agama. Seiring berjalannya waktu, makin hari tajug kecil itu pun makin sesak dengan anak-anak yang hendak mengaji. Dengan demikian, pada tahun 1970, K.H. Acep Dawud memutuskan untuk merubuhkan tajug tersebut, serta membangun sebuah masjid dan pesantren sederhana, guna lebih memfasilitasi anak-anak tersebut dalam menuntut ilmu. Semakin lama, semakin bertambah banyak pula anak-anak yang mengaji di Pondok Pesantren Riyadul Hikmah ini. Meskipun hanya santri kalong (santri yang tidak mondok di asrama), namun jumlahnya semakin bertambah.

Pada saat ini, Pondok Pesantren Riyadul Hikmah memiliki santri sekitar 70 
orang, yang terbagi menjadi dua, yaitu sekitar 30 orang santri yang menginap atau menetap di pesantren tersebut dan sebagian lagi merupakan santri kalong.Ada suatu hal yang unik di Pondok Pesantren Riyadul Hikmah ini, yakni tidak dipungut biaya sepeserpun. Para santri yang ingin menetap dan mondok di Pesantren Riyadul Hikmah, mereka tidak dibebankan untuk biaya pesantren, semua dijamin oleh pimpinan Pondok Pesantren Riyadul Hikmah, dari mulai makan, kitab, dan sebagainya. Mereka tidak akan dimintai biaya untuk membayar kehidupan mereka di pesantren asalkan mereka patuh, dan dapat membantu segala hal yang berkaitan dengan kegiatan di pesantren atau dapat membantu masyarakat di sekitar Desa Cintaasih.

\section{Kiprah Dakwah K.H. Acep Dawud di Masyarakat}

Di daerah perkampungan seperti Desa Cintaasih, menjadi seorang Kiai bukan hanya menjadi seorang ahli agama, melainkan juga dituntut untuk menjadi orang yang serba bisa. Tidak sedikit warga yang mengira bahwa K.H. Acep Dawud adalah orang serba bisa, hingga warga pun mulai berdatangan kepada beliau dengan membawa berbagai persoalan hidup mereka masing-masing, dari mulai gagal panen, sakit, jodoh, pekerjaan, dan lain sebagainya.

Perlu diketahui, bahwa jauh sebelum K.H. Acep Dawud mendalami ilmu tasawuf dan hikmah (mistisisme Islam), Desa Cintaasih (yang terkenal dengan Cibenda) merupakan sarang para dukun ilmu hitam. Ketenaran dukun-dukun Cibenda di Kabupaten Bandung Barat, setara dengan ketenaran dukun-dukun Jampang di Sukabumi, atau dukun-dukun Miramareu di Garut Selatan. Saking tenarnya dukun-dukun Cibenda ini, bahkan sampai terjadi peristiwa yang menyantet si A adalah dukun Cibenda, sedangkan yang mengobati si A dari santetnya adalah tetangga dukun yang menyantet. Bahkan, beberapa rumor beredar bahwa jika seseorang terkena santet dukun Cibenda, maka yang dapat mengobati hanyalah dukun Cibenda yang lainya.

Oleh karena itu, diusianya yang masih relatif muda, K.H. Acep Dawud membuka praktik konsultasi dan memberikan ijazah doa-doa serta ayat-ayat alquran kepada masyarakat, guna menandingi kiprah para dukun di Cintaasih. Selain itu, masyarakat Cintaasih pada masa itu pun merupakan masyarakat yang sangat percaya sekali dengan praktik klenik perdukunan di Cibenda Cintaasih. Hal inilah yang melatarbelakangi K.H. Acep Dawud untuk mendalami ilmu hikmah dan tasawuf serta melakukan gerakan dakwah di Desa Cintaasih dengan pendekatan dialog keagamaan.

Hadirnya K.H. Acep Dawud dengan gerakan konsultasinya berupa dialog, disambut dengan baik oleh warga sekitar. Hal ini ditenggarai karena begitu sulitnya syarat-syarat yang diajukan oleh para dukun guna membantu pasiennya. Tidak jarang si pasien harus menyediakan sesajen-sesajen dengan barang-barang yang cukup sulit didapatkan seperti ayam cemani, telur ayam kampung dara dan sebagainya. Selain itu, masalah biaya pun menjadi salah satu faktor penyebab 
Tabligh K.H. Acep Dawud Melalui Pendekatan Dialog Keagamaan beralihnya masyarakat dari praktik perdukunan, kepada praktik dialog keagamaan K.H. Acep Dawud. Tidak hanya sebagai seorang atau sosok mubaligh yang menekuni bidang dialog sebagai metode dakwahnya, K.H. Acep dawud juga merupakan sosok yang sangat disegani tetapi mempunyai sifat yang sangat ramah dan baik hati, sebagaimana pula diungkapkan (Sihabudin, 2019: 69) bahwa seorang mubaligh/da'i harus mempunyai sikap yang baik sebagai bahan pertimbangan mad'u dan sebagai contoh yang harus diteladani oleh mad'unya.

Tidak dapat dipungkiri, bahwa sudah menjadi fitrah manusia untuk terus mencari sesuatu yang lebih memudahkan hidupnya. Sebagaimana Allah Swt. berfirman dalam surat al-Baqarah 185:

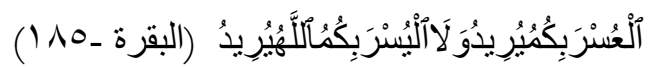

"Allah menghendaki kemudahan bagimu, dan tidak menghendaki kesukaran bagimu" (Depag, 2010: 28).

Hal itu pulalah yang terjadi pada masyarakat Desa Cintaasih. Mereka berduyun-duyun beralih dari praktik perdukunan yang menyulitkan mereka untuk mencari barang-barang sesajen yang langka serta berbiaya mahal, kepada praktik dialog K.H. Acep Dawud yang hanya mensyaratkan mereka untuk shalat lima waktu dan membaca ayat-ayat suci Alquran, serta cukup memberi alakadarnya atas jasa beliau. Bahkan sebagian dari mereka hanya memberikan sebagian kecil dari hasil buminya sebagai tanda terima kasih kepada K.H. Acep Dawud, atau bahkan sebagian dari mereka tidak memberi apapun kepada beliau.

Keikhlasan K.H. Acep Dawud menjadi kunci utama kesuksesan kiprah dakwahnya di Cintaasih. Masyarakat tidak mampu yang memiliki masalah dan tidak sanggup membayar dukun-dukun Cintaasih, menjadi sangat terbantu dengan kehadiran K.H. Acep Dawud yang tanpa pamrih. Selain itu, keberhasilan yang dikabarkan oleh klien-klien beliu pun menjadi salah satu faktor utama bagi kiprah dakwah beliau guna memberangus praktik perdukunan di Desa Cintaasih.

Semakin hari, kepopuleran K.H. Acep Dawud semakin terendus banyak orang diberbagai kalangan, dari mulai para petani setempat hingga para pejabat dan calon anggota dewan. Tidak hanya di lingkungan Kabupaten Bandung Barat saja, melainkan hingga keluar pulau seperti Aceh, Maluku, Gorontalo, Pontianak, Nusa Tenggara, bahkan hingga ke manca negara seperti Malaysia, Brunai, Arab Saudi, Singapura, dan lain sebagainya.

Tidak dapat dipungkiri lagi, bahwa kepopuleran beliau menimbulkan kecemburuan sosial di kalangan para dukun-dukun Cintaasih yang kian hari kian sepi dari pasiennya. Keberadaan K.H. Acep Dawud menjadi momok yang sangat mengancam eksistensi para dukun Cintaasih ini. Hingga pada suatu hari, para dukun tersebut beraliansi guna menjegal kiprah dakwah K.H. Acep Dawud. Para dukun ini pun mengirimkan wabah penyakit kulit (buduk) ke kampung tempat K.H. Acep Dawud tinggal. Alhasil seluruh warga kampung tersebut kecuali K.H. Acep Dawud mengalami penyakit kulit (buduk) kiriman para dukun. 
Selama tujuh bulan penduduk kampung secara bergiliran mengalami penyakit kulit tersebut. K.H. Acep Dawud pun sibuk mengobati penduduk kampung dengan penyakit yang sama. Namun, atas izin Allah Swt. wabah penyakit itu pun akhirnya dapat di atasi dengan baik. Usai menghadapi wabah penyakit kiriman tersebut, atas izin Allah pula, wabah penyakit itu menyerang balik kampung para dukun yang semula berniat jahat pada K.H. Acep Dawud dan warganya.

Melalui peristiwa itulah, para dukun Cibenda yang mulanya berniat jahat kepada K.H. Acep Dawud, akhirnya mengakui kesalahan mereka dan bertaubat kepada Allah Swt. Sebagian besar dari mereka berbondong-bondong mendatangi kediaman K.H. Acep Dawud guna mengobati penyakit kulit tersebut, karena mereka sendiri tidak mampu untuk mengobati penyakit itu dengan ilmu perdukunannya. Namun, sebagian kecil lainnya ada pula dukun-dukun yang lari meninggalkan Desa Cintaasih menuju ke pelosok gunung yang masih dikawasan Kabupaten Bandung Barat guna menghindari K.H. Acep Dawud serta membuka praktik baru disana. Mereka yang bertaubat dan mendatangi K.H. Acep Dawud, beberapa orang ada yang memutuskan untuk mengabdi di pesantren beliau, namun beberapa orang lagi ada pula yang memilih untuk kembali ke rumah mereka masing-masing guna menjalani profesi lain selain dukun.

Sejak peristiwa itu, perjalanan dakwah K.H. Acep Dawud dalam membimbing masyarakat Cintaasih ke arah yang lebih baik semakin lancar bahkan cenderung tanpa hambatan yang berarti. Bisa dikatakan bahwa perlawanan beliau terhadap para dukun-dukun Cintaasih menjadi perjalanan dakwah beliau yang paling berat. Namun demikian, melalui peristiwa itulah, sosok K.H. Acep Dawud menjadi sangat disegani dan dikagumi oleh masyarakat, bahkan menjadi sangat populer di berbagai tempat bahkan berbagai kalangan. Oleh sebab itu pula, gerakan dakwah beliau semakin efektif, serta pemikiran dan ajaran-ajaran beliau menjadi sangat menyebar luas hingga kepelosok-pelosok negeri bahkan ke manca negara. 


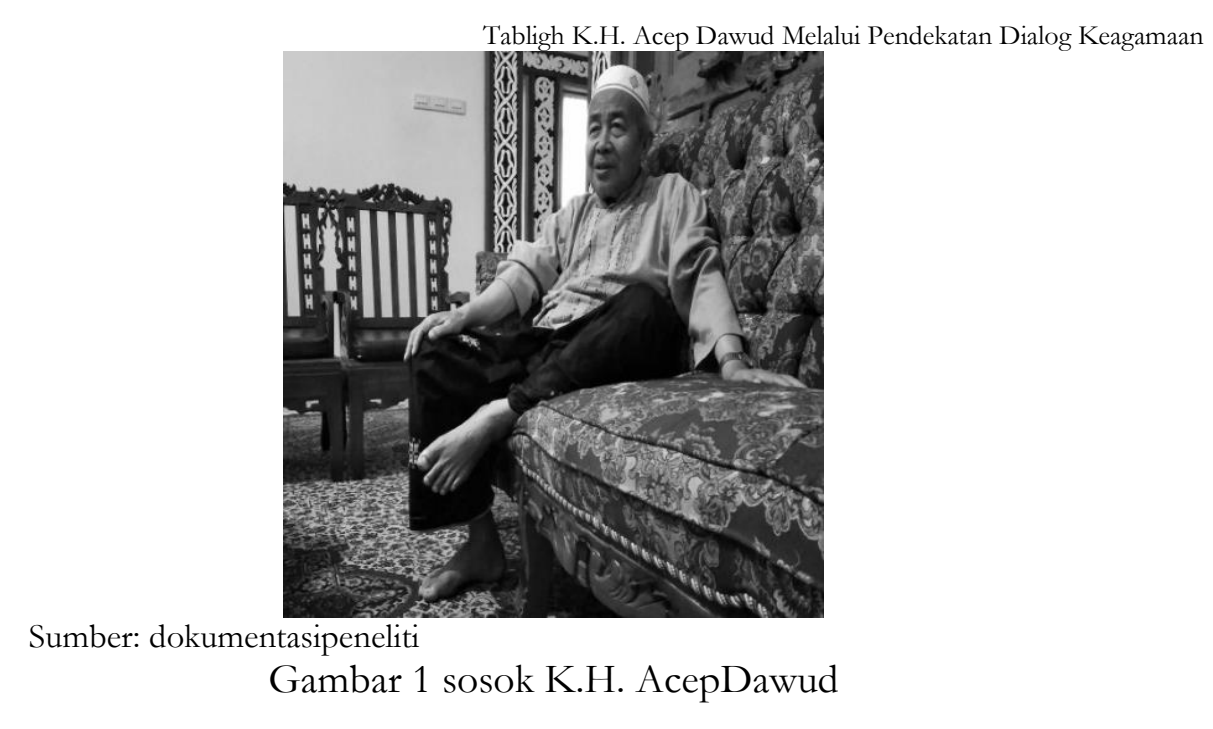

\section{Proses Tabligh K.H. Acep Dawud di Masyarakat}

Sebagaimana yang telah diketahui, bahwa pendekatan tabligh yang digunakan oleh K.H. Acep Dawud adalah dengan menggunakan pendekatan dialog keagamaan. M. Ali Aziz mengemukakan bahwa, dialog merupakan wawancara secara individual atau tatap muka antara seorang konselor (mubaligh) yang profesional dengan klien (mubalagh) untuk memecahkan masalah yang dihadapinya (Aziz, 2009: 372). Hal ini pulalah yang dilakukan oleh K.H. Acep Dawud di Pondok Pesantren Riyadul Hikmah kepada klien atau mubalaghnya. Beliau mewawancarai mubalaghnya secara tatap muka, guna mengorek lebih dalam tentang masalah apa yang dihadapinya. Wawancara tersebut dilakukan secara pribadi dan tertutup didalam sebuah kamar khusus, untuk menjaga privasi dari sang mubalagh, jika memang masalahnya bersifat pribadi, berbeda jika masalahnya bersifat umum, biasanya kegiatan konsultasinya dilakukan di ruang tamu.

Adapun dalam kegiatan dialog, Juhana Wijaya mengemukakan bahwa terdapat tiga teknik dalam proses pelaksanaan dialog, yakni pertama, teknik nondirektif. Pada teknik ini, seorang konselor atau mubaligh meyakini bahwa mitra dakwah memiliki kemampuan sendiri untuk menyelesaikan masalahnya sendiri. Kedua, teknik direktif. Teknik ini merupakan kebalikan dari teknik non-direktif, dimana konselor atau mubaligh memandang mitra dakwahnya sebagai orang yang tidak memiliki kemampuan penuh untuk menyelesaikan masalahnya sendiri. Ketiga, teknik eklektik. Teknik ini adalah penggabungan dari dua teknik konsultasi sebelumnya, dimana konselor atau mubaligh menggunakan dua teknik konsultasi diatas secara fleksibel tergantung dari masalah yang sedang dihadapi oleh mitra dakwah (Aziz: 2009: 373).

Merujuk pada teori yang dikemukakan oleh Juhana Wijaya ini, proses dialog keagamaan yang dilakukan oleh K.H. Acep Dawud dapat dikatagorikan 
sebagai proses dialog eklektik, dimana beliau selaku mubaligh menggabungkan teknik direktif dan non-direktif terhadap kliennya, tergantung pada masalah apa yang dihadapi oleh mubalaghnya tersebut.

Untuk masalah mubalagh yang bersifat sangat privasi sperti perceraian, mencari jodoh, keharmonisan dalam rumah tangga, hutang-piutang, caleg atau calon bupati yang ingin menang, dan lain sebagainya, K.H. Acep Dawud menggunakan teknik non-direktif, dimana beliau hanya memberikan petuahpetuah bijaknya serta membekali mubalaghnya dengan bacaan atau doa-doa yang harus dibaca oleh kliennya ba'da shalat lima waktu. Dalam masalah seperti ini, beliau memberikan arahan terkait hukum-hukum yang berlaku dalam agama Islam tentang masalah yang dihadapi oleh mubalaghnya. Seperti saat ada mubalagh yang mendatangi beliau dengan maksud ingin berpisah dengan pasangannya, maka K.H. Acep Dawud selalu berusaha untuk membujuk mubalaghnya mengurungkan niatnya bercerai. Beliau memberikan nasehat pada mubalaghnya bahwa perceraian merupakan pekerjaan yang diperbolehkan oleh agama namun dibenci oleh Allah Swt. Beliau berusaha memberikan opsi lain kepada mubalaghnya selain dengan perceraian, bahkan beliau membekali mubalagh tersebut dengan bacaan atau doa-doa guna merekatkan kembali hubungan mubalagh dengan pasanganya.

Jika mubalaghnya merupakan seorang calon legislatif, calon gubernur, calon bupati yang hendak maju dalam pemilihan dan berharap menang, maka K.H. Acep Dawud memberikan nasehatnya tentang pentingnya menerima segala takdir yang telah Allah Swt. gariskan. Menurut beliau, cara terbaik dan tercepat untuk mendapatkan ridha Allah Swt. adalah dengan cara orang itu ridha dengan apa yang telah dan akan Allah Swt. berikan kepada orang tersebut. Menghadapi mubalagh yang seperti itu, K.H. Acep Dawud tidak pernah menjanjikan bahwa ia akan 100\% menang dalam pemilihan, namun beliau selalu menasehati mubalaghnya tersebut dalam mengantisipasi setiap kemungkinan terburuk yang akan terjadi dalam pemilihan.

Namun apabila masalah mubalaghnya bersifat umum seperti pembagian hak waris, ingin usahanya maju, ingin tanah atau rumah yang ia jual cepat laku, dan lain sebagainya, maka disamping memberikan petuah bijak dan membekali mubalaghnya dengan bacaan dan doa yang harus ia baca, K.H. Acep Dawud pun tidak jarang terjun langsung kelokasi guna melakukan ritual di lokasi tersebut.

Ritual yang dilakukan oleh K.H. Acep Dawud jika keadaan memaksanya untuk terjun langsung kelokasi, adalah ritual-ritual ke-Islaman biasa seperti shalat sunat, membaca ayat-ayat Alquran, membaca doa-doa khusus, atau menanam wafaq/rajah tulisan tangan beliau sendiri. Ritual dilokasi tersebut, dilakukan oleh K.H. Acep Dawud paling singkat dalam waktu satu malam dan paling lama bisa mencapai satu minggu. Dengan kata lain, dalam melakukan ritual-ritual itu K.H. Acep Dawud tidak melakukan ritual yang menyimpang dari ajaran syari'at Islam. 
Dalam setiap kegiatan dialog yang dilakukan oleh KH. Acep Dawud, beliau tidak pernah mematok tarif yang harus dibayarkan oleh mubalaghnya. Beliau cenderung melakukan dialog keagamaannya dengan suka rela, tanpa mengharapkan imbalan yang harus beliau terima. Maka beberapa tamu khususnya para tetangga, yang datang berkonsultasi dengan beliau tanpa memberikan imbalan apapun kepada beliau. Dengan kata lain, kegiatan dialog keagamaan yang dilakukan oleh K.H. Acep Dawud di Pondok Pesantren Riyadul Hikmah tidak dapat disebut sebagai pekerjaan, melainkan lebih kepada pengabdian masyarakat.

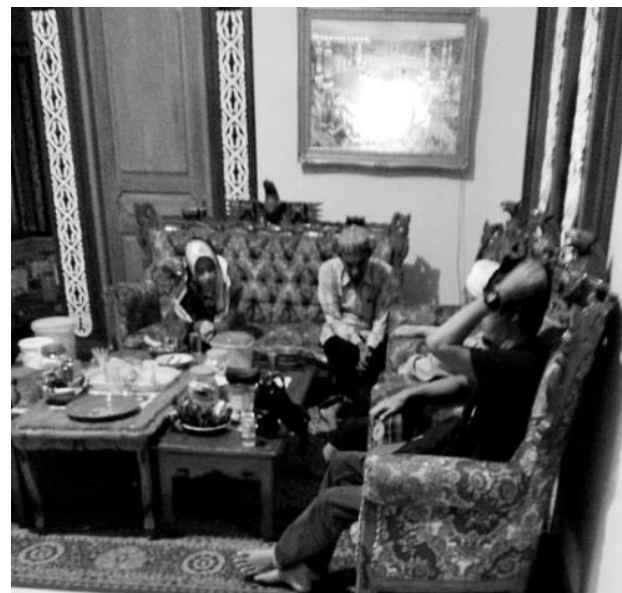

Sumber: dokumentasi peneliti

Gambar 2 proses dialog denganparatamu

\section{Materi Tabligh K.H. Acep Dawud di Masyarakat}

Pesan atau materi dalam komunikasi adalah apa yang diungkapkan oleh komunikator kepada komunikan. Menurut Dominick yang dikutip oleh Morissan, pesan merupakan sebuah produk yang dihasilkan oleh sumber melalui proses enkoding (Morissan, 2013: 19). Sedangkan untuk enkoding sendiri, merupakan suatu proses yang dilakukan oleh sumber guna menafsirkan pikiran, ide, dan gagasannya kedalam suatu bentuk yang dapat diterima oleh penerimanya (Morissan, 2013: 18). Mesti dibedakan antara pesan dan enkoding. Enkoding adalah kegiatan yang terjadi di dalam otak seorang sumber untuk menghasilkan pesan. Sedangkan pesan merupakan hasil dari kegiatan enkoding, yang dapat dirasakan atau diterima oleh penerima.

Dengan kata lain, ketika seseorang berkata, maka apa yang ia katakan adalah pesan. Ketika seseorang menuliskan sesuatu, maka apa yang ia tuliskan adalah pesan. Pun demikian ketika seseorang menonton televisi atau film, maka apa yang ia tonton adalah pesan.

Dalam kegiatan komunikasi, pesan (massage) menjadi unsur yang sangat penting, mengingat tujuan dari kegiatan komunikasi ialah tersampaikannya 
sebuah pesan dari komunikator kepada komunikan. Demikian pula dengan kegiatan tabligh. Menurut Samsul Munir Amin, pesan dakwah adalah segala sesuatu yang mesti disampaikan oleh subjek (da'i) kepada objek (mad'u), yang berupa keseluruhan ajaran Islam yang tercantum dalam Qur'an dan Hadits (Amin, 2009: 88).

Lebih jauh Basit mengemukakan bahwa, pesan tabligh terkait dengan tiga hal (Basit, 2013: 140-141). Pertama, materi tabligh menjabarkan sederet kata atau imajinasi yang berkenaan dengan dakwah, yang gambarkan dengan kata-kata. Dalam hal ini pesan tabligh mengandung dua unsur, yakni isi pesan yang merupakan pikiran dari sang mubaligh dan simbol, yang dalam hal ini berupa kata atau bahasa.

Kedua, materi tabligh berkaitan dengan persepsi seseorang atas makna dari pesan tersebut. Makna merupakan suatu proses aktif yang dihasilkan dari kerjasama antara mubaligh dan mubalagh. Memahami makna atas apa yang akan disampaikan serta bagaimana cara menyampaikannya, akan membantu seorang mubaligh untuk memaksimalkan pengelolaan pesan. Makna juga tidak hanya terkait dengan pesan, namun juga terkait dengan interaksi pesan dengan pemikiran dan suasana hati penerima pesan. Untuk memahami makna tidak cukup dengan hanya melihat kata-katanya saja, melainkan juga perlu melihat orang yang memberikan makna tersebut.

Ketiga, kegiatan penerimaan pesan atau materi tabligh yang dilakukan oleh mubalagh. Pesan tabligh memiliki keterbukaan untuk ditafsirkan dan dipahami secara berbeda oleh berbagai macam mubalagh. Namun, tetap saja ada kesepakatan bersama antara mubaligh dan mubalagh, yang memungkinkan terjadinya kegiatan tabligh. Dengan kata lain, penerimaan pesan tabligh tidak bisa mencapai kesempurnaan, mengingat banyak faktor yang bisa menghambat proses tersebut, seperti faktor situasi, kondisi psikologis mubalagh, waktu penyampaian, dan kemampuan mubaligh.

Menurut Aep Kusnawan, sejatinya suatu pesan atau materi dapat dikatakan sebagai pesan tabligh jika di dalamnya terkandung tiga aspek, yang ketiga aspek tersebut sama-sama menjabarkan nilai-nilai keilahian (Kusnawan, dkk, 2004: 47). Pertama, adalah aspek kognitif. Yang dimaksud dengan aspek kognitif ini adalah cara berpikir. Pesan tabligh sejatinya mesti dapat menjabarkan nilai-nilai keilahian dalam cara berpikir tersebut. Kedua, adalah aspek afektif. Yang dimaksud dengan aspek afektif ini adalah aspek rasa atau emosi. Pesan atau materi tabligh haruslah menjabarkan nilai keilahian dalam aspek rasa ini. Ketiga, adalah aspek psikomotorik, yang dimaksud dengan aspek psikomotorik ini adalah aspek pergerakan informasi atau pesan. Dalam pesan tabligh, nilai-nilai keilahian haruslah bisa dijabarkan dalam aspek pergerakan informasi atau pesan ini.

Jika dilihat dari sisi jenisnya, maka pesan tabligh terbagi pada tiga dimensi, 
Tabligh K.H. Acep Dawud Melalui Pendekatan Dialog Keagamaan

pertama, Dimensi Akidah. Secara etimologis, kata akidah berarti "ikatan", sedangkan secara teknis, akidah dapat diartikan iman, kepercayaan, atau keyakinan (Anshari, 2004: 44). Iman adalah suatu jaminan guna menghadapi ketakutan dan kekecewaan dalam lika-liku kehidupan (Thabathaba'i, 1992: 23). Iman sendiri memiliki makna dasar "yakin". Sejatinya kepercayaan dan keimanan merupakan sesuatu yang berbeda. Ketika seseorang mengatakan bahwa ia percaya dengan suatu hal, maka maksudnya adalah mereka mempercayai suatu hal yang mereka anggap benar, padahal seringkali ternyata kepercayaan itu salah dan hanya mengawang-ngawang belaka. Lain halnya dengan iman, yang merupakan kepercayaan kepada suatu kebenaran yang hakiki, bukan kebenaran yang disodorkan (Murata, \& Chittick, 2005: 50).

Akidah adalah pondasi dari ajaran Islam. Menurut Harun Nasution, akidah lahir dari ajaran paling dasar dalam Islam, yakni keimanan (Nasution, 1995: 347). Dengan kata lain, pembahasan berkenaan dengan akidah pada umumnya berbicara tentang rukun iman yang enam, yakni iman kepada Allah, iman kepada malaikat, iman kepada kitab-kitab Allah, iman kepada para Nabi Allah, iman kepada hari kiamat, serta iman kepada qada dan qadar (Anshari, 2004: 44). Keimanan tidaklah cukup hanya beriman kepada Allah, melainkan juga perlu untuk beriman kepada objek-objek lain seperti disebutkan diatas. Karena jika seseorang tidak beriman kepada semua objek yang disebutkan, maka orang itu tidak bisa dikatakan sebagai keimanan Islam, melainkan keimanan yang lain (Murata, \& Chittick, 2005: 49).

Jika ditinjau dari segi pesan atau materi tabligh, berdasarkan uraian diatas, maka materi tabligh dapat dikategorikan kedalam dimensi akidah jika didalam materi tersebut terkandung salah satu dari nilai-nilai keimanan kepada Tuhan, malaikat, kitab-kitab Allah, para Nabi, hari akhir, serta qada dan qadar. Jika tidak ada salah satu dari nilai-nilai tersebit, maka pesan tersebut tidak dapat dikatakan sebagai materi tabligh dalam dimensi akidah.

Dalam kegiatan dialog yang dilakukan oleh K.H. Acep Dawud, salah satu materi tabligh yang selalu beliau sampaikan kepada mubalaghnya adalah pesan akidah, khususnya materi-materi mengenai keimanan kepada Allah swt., hari akhir, serta qada dan qadar. Dari hasil pengamatan di lokasi penelitian, KH. Acep Dawud senantiasa selalu menyisipkan materi-materi akidah ini pada setiap mubalaghnya yang datang. Beliau selalu mengingatkan mubalaghnya agar senantiasa mendekatkan diri kepada Allah Swt. guna menyelesaikan masalahmasalah yang dihadapinya, serta mengingatkan kliennya bahwa segala sesuatu yang terjadi merupakan kehendak dari Allah Swt. Melalui pengamatan itulah, dapat disimpulkan bahwa materi atau pesan-pesan dialog keagamaan yang dilakukan oleh K.H. Acep Dawud bermuatan materi tabligh dalam katagori dimensi akidah.

Dimensi kedua dari pesan atau materi tabligh adalah dimensi syari'ah. 
Secara etimologi syari'ah berarti “jalan”. Syari'at Islam merupakan suatu norma Ilahi yang mengatur hubungan antara manusia dengan Tuhan, manusia dengan manusia, dan manusia dengan alam. Lebih jauh Muhammad Hashim Kamali seorang pakar hukum Islam internasional berpendapat bahwa, syari'at adalah jalan menuju agama, yang didalamnya meliputi nilai-nilai yang esensial bagi Islam. Sejatinya syari'ah terbagi kedalam dua bagian, yakni 'ubudiyah dan mu'amalah (Kamali, 2013: 5). Dalam bagian 'ubudiyah (ibadah), terkenal lima pilar yang akrab disebut rukun Islam, yakni syahadat, shalat, puasa, zakat, dan haji. Kelima pilar tersebut merupakan bagian pokok dalam kegiatan ibadah kepada Tuhan (bablu min Allah).

Sedangkan dalam bagian mu'amalah (transaksi sipil), norma Ilahi mengatur hubungan antara manusia dengan manusia dan manusia dengan alam. Mu'amalah dalam arti luas terbagi pula kedalam dua bagian besar, pertama, al-qanun al-khas (hukum perdata) yang meliputi perdagangan, pernikahan (munakahat), warisan (warasat), dan sebagainya. Sedangkan bagian yang kedua, al-qanun al-'am (hukum publik) yang meliputi hukum pidana (jinayah), hukum kenegaraan (khilafah), politik (Siyasah) dan lain sebagainya.

Dari uraian diatas, jika ditinjau dari segi pesan atau materi tabligh, maka materi tabligh dapat dikategorikan sebagai materi atau pesan yang berdimensi syari'ah jika didalamnya termuat nilai-nilai 'ubudiyyah dan atau nilai-nilai mu'amalah. Jika suatu pesan tidak mengandung salah satu dari dua bagian tersebut, maka pesan tersebut tidak bisa dikategorikan sebagai pesan atau materi tabligh dalam dimensi syari'ah.

Dari hasil observasi dilapangan, materi yang disampaikan oleh K.H. Acep Dawud di Pondok Pesantern Riyadul Hikmah dapat dikatagorikan sebagai materi tabligh berdimensi syari'ah. Hal ini dapat dibuktikan dari setiap kegiatan dialog nya yang dilakukan oleh K.H. Acep Dawud terhadap mubalaghnya, dimana beliau selalu memberikan bacaan-bacaan doa yang mesti dibaca oleh mubalaghnya setelah shalat lima waktu. Hal tersebut dilakukan guna memaksa mubalaghnya agar senantiasa melaksanakan shalat lima waktu. Materi tabligh ini dikatagorikan sebagai materi tabligh dimensi syari'ah bagian 'ubudiyah, dimana K.H. Acep Dawud menekankan aspek hablu min Allab kepada mubalaghnya.

Selain 'ubudiyah, dalam materi tabligh dimensi syari'ah-nya, K.H. Acep Dawud juga kerap memberikan materi yang bermuatan mu'amalah. Hal ini dapat dibuktikan ketika ada beberapa mubalaghnya yang datang guna dialog mengenai pembagian waris, perceraian dan pernikahan, atau urusan-urusan politik seperti pencalonan Bupati, Gubernur, anggota legislatif, dan lain sebagainya. Dalam praktiknya, K.H. Acep Dawud senantiasa memberikan arahan-arahan tentang hukum waris, pernikahan dan perceraian, dan lain sebagainya secara Islam kepada kliennya. Dengan kata lain, materi-materi tabligh yang dikemukakan oleh K.H. Acep Dawud dalam kegiatan dialog keagamaanya dapat dikatagorikan 
sebagai materi tabligh dimensi syari'ah.

Dimensi ketiga dari pesan atau materi tabligh adalahdimensi Akhlak. Secara etimologis, akhlak dapat diartikan perbuatan, perangai, tabiat, atau kebiasaan. Pembinaan akhlak yang baik adalah salah satu pokok dari ajaran Islam (Nasution, 1995: 60). Bahkan suatu hadits mengatakan innama bu'istu li utammima makarim al-akhlaq, sesungguhnya aku hanya diutus untuk menyempurnakan akhlak yang mulia. Akhlak dalam ajaran Islam tidak dapat disamakan dengan etika. Jika etika hanya diartikan sebgai perilaku sopan santun antar sesama manusia dan hanya berkaitan pada perilaku lahiriyah saja, maka akhlak jauh lebih luas dari pada itu (Shihab, 2004: 261).

Akhlak juga berkaitan dengan hal-hal yang bukan merupakan sifat lahiriyah. Seperti yang berkaitan dengan sifat-sifat batiniyah atau pikiran. Setidaknya akhlak menyangkut tiga aspek, yakni bablu min Allab (hubungan antara manusia dengan Tuhan) hablu min al-nas (hubungan antar sesama manusia) dan hablu min al-'alam (hubungan manusia dengan alam.

Yang menjadi titik tolak akhlak manusia terhadap Tuhan adalah kesadaran serta pengakuan orang tersebut bahwa tiada Tuhan selain Tuhan yang Esa (Allah). Ekspresi dari keyakinan tersebut mesti diimplementasikan dalam ucapan, perbuatan, serta keyakinan manusia (Shihab, 2004: 261-266). Sedangkan untuk akhlak kepada sesama manusia banyak sekali yang dikemukakan oleh al-Qur'an. Tidak hanya berbentuk larangan melakukan sesuatu yang negatif yang bersifat fisik seperti membunuh, mencederai, merampas dan sebagainya, namun juga sampai pada menyakiti hati dengan cara menceritakan aib orang lain. Tak hanya itu, kejujuran, bersikap adil, bersikap sopan, dan lain sebagainya pun tercantum dalam al-Qur'an (Shihab, 2004: 266-269).

Sedangkan untuk akhlak terhadap alam atau lingkungan, pada dasarnya bersumber dari posisi manusia sebagai khalifah di bumi. Seorang khalifah Tuhan (wakil Tuhan) jelas bertugas untuk melestarikan, mengurus, serta memanfaatkan alam dengan sebaik-baiknya. Yang dimaksud alam dalam konteks ini adalah segala sesuatu yang berada disekitar manusia, baik tumbuhan, hewan, ataupun benda mati. Dalam pandangan akhlak Islam, seseorang dilarang untuk memetik buah sebelum matang, atau memetik bunga sebelum mekar. Hal ini dikarenakan jika berprilaku seperti itu, sama halnya dengan tidak memberikan kesempatan kepada ciptaan tersebut untuk mencapai tujuan dari penciptaanya. Dengan kata lain, manusia dituntut untuk menghormati proses yang tengah terjadi. Hal tersebut dimaksudkan agar manusia dapat bertanggung jawab serta tidak melakukan perusakan (Shihab, 2004: 269-270).

Jika ditinjau dari segi pesan dakwah, maka suatu pesan dapat dikatakan pesan dakwah dalam dimensi akhlak, jika pesan tersebut mengandung nilai-nilai bablu min Allah, hablu min al-nas, dan hablu min al-'alam. Jika pesan tersebut tidak mengandung salah satu dari nilai-nilai akhlak kepada Tuhan, kepada sesama, dan 
kepada alam, maka pesan tersebut tidak bisa dimasukkan kedalam kategori pesan dakwah dalam dimensi akhlak.

Dari hasil observasi yang dilakukan pada kegiatan dialog keagamaan K.H. Acep Dawud, memang tidak ditemukan secara gamblang mengenai materimateri tabligh yang disampaikan terkait dimensi akhlak. Namun demikian, ketika mubalagh yang datang ber dialog pada beliau mengenai masalah-masalah pribadi seperti masalah hutang-piutang, masalah waris, masalah perceraian, perselingkuhan, dan lain sebagainya, K.H. Acep Dawud kerap memberikan petuah-petuah bijak mengenai pentingnya menghargai hak orang lain dan menghargai perasaan orang lain.

Contoh kasus, ketika seorang mubalagh datang untuk berdialog tentang masalah hubungan rumah tangganya, K.H. Acep Dawud selalu menasehati klien tersebut agar senantiasa mengalah pada pasangannya, menjaga keharmonisan keluarganya, tidak serta merta terbawa emosi dalam mengambil keputusan bersama keluarganya dan lain sebagainya. K.H. Acep Dawud selalu berpesan pada klien tersebut untuk tidak mencederai perasaan orang lain, karena bisa saja kesusahan yang ia alami merupakan bentuk karma dari kelakuannya terhadap orang lain. Menurut beliau, jika seseorang melakukan dosa kepada Allah Swt., sangat mudah untuk mendapatkan ampunan dari-Nya, hanya tinggal bertaubat dengan sungguh-sungguh dan berjanji untuk tidak melakukan dosa yang sama. Akan tetapi, jika seseorang berbuat salah kepada orang lainnya, maka belum tentu beribu maaf dapat diterima oleh orang tersebut.

Dengan kata lain, secara tidak langsung, materi-materi tabligh yang disampaikan oleh K.H. Acep Dawud dalam kegiatan dialog keagamaannya di Pondok Pesantren Riyadul Hikmah, dapat pula dikategorikan sebagai materi tabligh berdimensi akhlak. Hal ini dikarenakan beberapa materi tabligh yang beliau sampaikan mengandung muatan-muatan untuk saling menghargai sesame manusia, menghargai hak-hak orang lain, dan menjaga hubungan baik dengan sesama.

\section{PENUTUP}

Metode merupakan sebuah cara yang dilakukan guna menyampaikan suatu pesan kepada khalayak. Terdapatbeberapa metode tabligh yang di gunakan oleh para mubaligh dalam menyampaikan pesan tablighnya, salah satunya yaitu metode dialog yang dilakukan oleh K.H. Acep Dawud.Kiprah dakwah K.H Acep Dawud dalam tabligh melalui pendekatan dialog keagamaan yaitu menghapuskan penyimpangan keagamaan seperti praktik-praktik perdukunan dan klenik. Selain itu juga beliau banyak membantu masyarakat dalam menyelesaikan masalah-masalah mereka dengan solusi yang dianggap memudahkan mereka. 
Kegian dialog tersebut dilakukan secara fleksibel, dimana K.H. Acep Dawud tidak selalu memposisikan dirinya sebagai orang yang harus menyelesaikan segala persoalan yang dihadapi oleh mubalaghnya. Terkadang, beliau hanya memberikan petuah-petuah bijaknya kepada mubalaghnya tanpa harus turun tangan membantu mubalaghnya tersebut, namun terkadang pula beliau pun harus ikut turut serta dalam menyelesaikan masalah mubalagh tersebut. Proses dialog yang dilakukan oleh K.H. Acep Dawud ini sejalan dengan teori diskusi eklektik, dimana seorang mubaligh menggabungkan teori direktif dan non-direktif kepada mubalagh, tergantung pada masalah yang dihadapi oleh mubalaghnya tersebut. Oleh karena itu, kegiatan tabligh melalui pendekatan dialog yang dilakukan oleh K.H. Acep Dawud dapat dikatakan sebagai kegiatan tabligh dengan metode dialog yang sejalan dengan teori yang dikemukakan oleh M. Ali Aziz, yakni metode tabligh dialog dengan teknik eklektik.

Materi tabligh yang disampaikan oleh K.H. Acep Dawud dalam kegiatan dialog keagamaannya merupakan materi-materi yang bersifat faktual. Materi tabligh beliau merupakan respon dari permasalahan-permasalahan yang dikonsultasikan olehmubalag-mubalaghnya. Selain itu, materi-materi dialog keagamaan yang disampaikan oleh K.H. Acep Dawud ini sejalan dengan teori materi tabligh yang dikemukakan oleh Endang Saefudin Anshari, dimana materi dialog K.H. Acep Dawud termasuk kedalam tiga kategori materi tabligh, yakni materi akidah, materi syari'ah, dan materi akhlak. Oleh sebab itu, kegiatan dialog keagamaan yang dilakukan oleh K.H. Acep Dawud dapat disimpulkan sebagai salah-satu kegiatan tabligh yang menggunakan dialog sebagai metode penyampaiannya. Hal ini disebabkan karena semua materi-materi dialog beliau mengandung muatan-muatan materi tabligh.

Secara teoritis, penelitian ini hanya dapat dijadikan semacam informasi awal untuk mengembangkan kegiatan tabligh yang berbasis pada penggunaan metode dialog. Oleh karena itu, diharapkan penelitian ini dapat memberikan kontribusi kepada keilmuan tabligh yang berbasis pada penggunaan metode dialog.

Secara prkatis, diharapkan penelitian ini dapat menjadi inspirasi bagi para pelaku tabligh dalam mengembangkan kegiatan penyiaran Islam, untuk lebih mengedepankan budaya dialog, dengan menjunjung tinggi sifat kemanusiaan dalam menyikapi berbagai permasalahan yang dihadapi umat. Dengan kata lain, model dialog keagamaan merupakan salah satu bentuk pelatihan bagaimana menjadikan seorang mubaligh, sebagai orang yang lebih moderat, lebih berpikir toleran, serta bersifat inklusif, dan tidak terpaku pada tafsir-tafsir tekstualis.

Penelitian ini sejatinya hanya meneliti kegiatan dialog sebagai metode tabligh. Oleh karena itu, tentunya akan lebih terbuka peluang untuk penelitian yang lainnya, seperti mengkaji tentang media dialog, materi dialog, keragaman 
penyelesaian permasalahan melalui dialog, dan lain sebagainya. Oleh karenanya, penelitian ini diharapkan bisa menjadi tambahan rujukan bagi penelitianpenelitian selanjutnya.

\section{DAFTAR PUSTAKA}

Amin, S.M. (2009). Ilmu Dakwah: Jakarta: AMZAH.

Anshari, E.S. (2004). Wawasan Islam: Pokok-Pokok Pikiran Tentang Paradigma dan Sistem Islam, Jakarta: GemaInsani.

Aziz, M. A. (2009). Ilmu Dakwah, Jakarta: Kencana. Cet-3.

Bakran, H. (2001). Konseling dan Psikoterapi Islam, Yogyakarta: Fajar Pustaka Baru.

Basit, A. (2013). Filsafat Dakwah, Jakrta: Rajawali Pers.

Ceng, M. (2008). Pendekatan Tabligh Forum Silaturahmi Lembaga Dakwah Kampus Bandung Raya (FSLDK BARAYA) Terhadap Anak Jalanan (StudiDeskriptif Pada Anak Jalanan Dipinggir Rel Kereta Api Kiaracondong Bandung). Skripsi, Jurusan Komunikasi danPenyiaran Islam, UIN Sunan Gunung Djati, Bandung.

Depag RI. (1992). Alqur'an danTerjemah, Bandung: Jabal.

Farihah, I. \& Ismanto. (2018). Dakwah Kiai Pesisiran: Aktivitas Dakwah Para Kiai di Kabupaten Lamongan dalam Ilmu Dakwah: Academic Journal for Homiletic Studies, 12(1), 46-60.

Indah, P.P. (2018). Tabligh Melalui Media Sosial Line, Skripsi. Jurusan Komunikasi dan Penyiaran Islam, UIN Sunan Gunung Djati, Bandung.

Kamali, M.H. (2013). Membumikan Syari'ah: Pergulatan Mengaktualkan Islam. Bandung: Mizan.

Kusnawan, A. (2004). Ilmu Dakwah: Kajian Berbagai Aspek. Bandung: Pustaka Bani Quraisy.

Morissan, (2013).Teori Komunikasi. Bogor: Ghalia Indonesia.

Muhamad, S. (2008). Tabligh Ustad Hari Wibowo Melalui Media Wayang Golek (Si Cepot). Skripsi, Jurusan Komunikasi dan Penyiaran Islam, UIN Sunan Gunung Djati, Bandung.

Muhyiddin, A. (2002). Metode Pengembangan Dakwah. Bandung: CV. Pustaka Setia.

Murata, S. \& William C. C. (2005). The Vision of Islam. Yogyakarta: LkiS

Nasution, H. (1995). Islam Rasional: Gagasandan Pemikiran Prof. Dr. HarunNasution. Bandung: Mizan. Yogyakarta: LkiS

Quthub, S. (1984). Fi Zhilal al-Qur'an, cet.10, jilid II. Beirut: Dar al- Syuruq.

Rafi'udin \& M.A.D. (1997). Prinsip-Prinsip Strategi Dakwah. Bandung: Pustaka Setia.

Ridwan, A. (2011). Ragam Khitobah Ta’tsiriyah; Sebuah Telaah Ontologis. dalam Jurnal IlmuDakwah: Academic Journal for homeletic Studies, 5(17), 
199-200.

Shihab, M. Q. (2008). Tafsir al-Mishbah. Jakarta: Lentera Hati.

Sihabudin, D. (2019). Komunikasi Dakwah Pada Masyarakat Adat Kampung Dukuh Garut dalam Jurnal Anida (Aktualisasi Nuansa Ilmu Dakwah), 19(1): 69.

Sukayat, T. (2009). Quantum Dakwah. Jakarta : PT. RinekaCipta.

Thabathaba'i, M.H. (1992). Inilah Islam: Upaya Memahami Seluruh Konsep Islam dengan Mudah. Jakarta: Pustaka Hidayah.

Saepulo, S. (2009). Model Komunikasi Dakwah Jamaah Tabligh. dalam Jurnal Ilmu Dakwah Academic Journal for homeletic Studies 4(14), 657-688.

Wijaya, J. (1998). Psikologi Bimbingan. Bandung: Eresco.

Willis, S. (2011). Konseling Keluarga. Bandung: Alfabeta. 